\title{
Long-term rise in a Sahelian water-table: the Continental Terminal in South-West Niger
}

\author{
C. Leduc ${ }^{a, *}$, G. Favreau ${ }^{\mathrm{a}, \mathrm{b}}$, P. Schroeter ${ }^{\mathrm{c}}$ \\ aIRD, UMR HSM, B.P. 5045, 34032 Montpellier Cedex, France \\ 'LHGI, Université Paris-sud, 91405 Orsay Cedex, France \\ ${ }^{c}$ La Acedia, 29690 Casares, Spain
}

Received 17 February 2000; revised 6 November 2000; accepted 8 November 2000

\begin{abstract}
The Continental Terminal water-table near Niamey (S-W Niger) has been the subject of a dense and detailed survey conducted over a period of almost $15 \mathrm{yr}$. The continuous rise in the groundwater level was unexpected but manifest and varied between 0.01 and $0.45 \mathrm{~m} \mathrm{yr}^{-1}$. As shown by corroborating measurements made throughout the twentieth century, this rise has been taking place for much longer and present levels are the highest ever recorded. Since the beginning of the 1960s, groundwater resources have increased by up to $150 \%$ ( $+15 \%$ on median), in spite of the severe droughts of the 1970 s and 1980 s. Based on isotopic data, infiltration is estimated at around $5 \mathrm{~mm} \mathrm{yr}^{-1}$ for median over the long-term. Hydrodynamic observations show that in recent years it has exceeded $20 \mathrm{~mm} \mathrm{yr}^{-1}$. The rise acceleration during the past decade is apparent from groundwater level chronicles. Even if fluctuations in rainfall may interfere, this phenomenon is mainly explained by a change in land-use. In this semi-arid area, intense land clearing has modified the hydraulic properties of the top $\mathrm{cm}$ of the soil and has consequently increased surface runoff. As runoff concentrates in temporary endoreic ponds and then infiltrates to the water-table, higher runoff implies higher groundwater recharge and a subsequent rise in the water-table. This is one of the best documented examples of a long-term rise of an African water-table in such a semi-arid context. (C) 2001 Elsevier Science B.V. All rights reserved.
\end{abstract}

Keywords: Groundwater; Natural recharge; Land-use; Semi-arid environment; Niger; Surface runoff

\section{Introduction}

It is generally assumed that a decrease in rainfall implies a decrease in surface runoff and also a decrease in groundwater recharge. In fact, changes in water resources are linked with climatic fluctuations, but also with environmental changes and human activities. The relative importance of each of these three factors depends on time and place. Hydro-

* Corresponding author. Fax: +33-4-67-14-47-74.

E-mail address: christian.leduc@mpl.ird.fr (C. Leduc). logical processes in arid and semi-arid areas are especially sensitive to small changes. Recent decades in the Sahel have been marked by annual rainfall well below or above average and by a rapid increase in population, both of which have an impact on the environment. Recent hydrological changes in this region therefore merit a detailed study.

The Niamey degree-square $\left(2-3^{\circ} \mathrm{E}, 13-14^{\circ} \mathrm{N}\right)$ was investigated during the Hapex-Sahel experiment, between 1991 and 1994. Initial interpretations of this hydrogeological survey have already been published (Leduc et al., 1997). This paper deals with

0022-1694/01/\$ - see front matter (C) 2001 Elsevier Science B.V. All rights reserved PII: S0022-1694(00)00403-0 

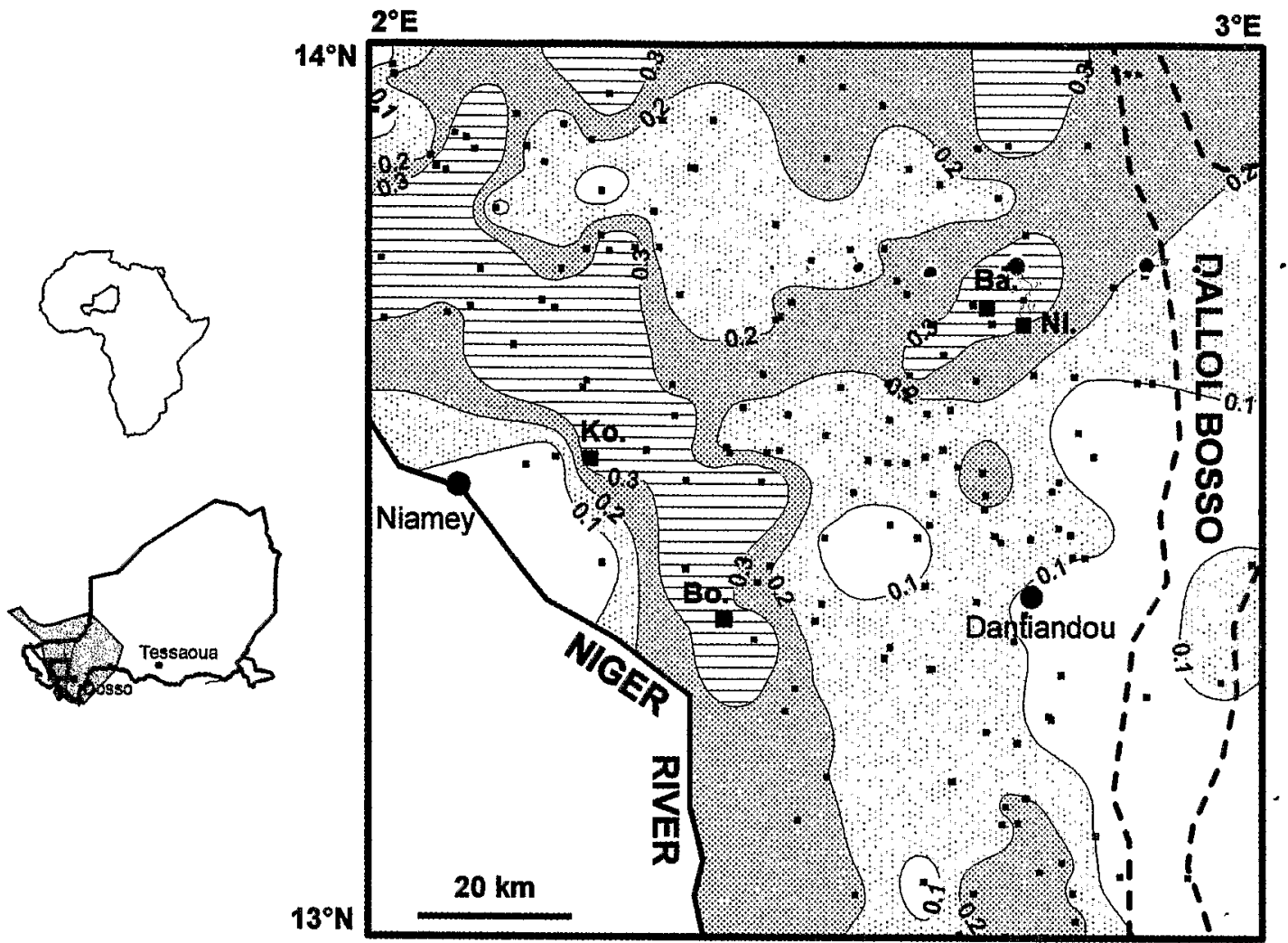

Fig. 1. Left, Niger with the extent of Continental Terminal in the Iullemmeden basin (shaded grey) and the Niamey degree square. Right, the interannual rise in the water-table during the 1990s in the Niamey degree (contours every $0.1 \mathrm{~m} \mathrm{yr}^{-1}$ ) and the village wells (small square dots) used to calculate this rise. Bo and $\mathrm{Ni}$ are detailed in Fig. 2 and Fig. 3, Ba and Ko are detailed in Fig. 2 only. Edges of the dallol Bosso fossil valley are indicated with a dashed line.

the water-table on the north-eastern side of the Niger river which covers an area of about $8000 \mathrm{~km}^{2}$ (Fig. 1). A large quantity of new data was collected during the five following years and a systematic analysis of former unpublished reports added many old scattered measurements (Favreau, 2000). We now dispose of a high density of reliable measurements, which is rather exceptional in semi-arid Africa.

The first part of this paper is a detailed analysis of changes in the water-table and in the water budget in the area over the last four decades, if not beyond. Present levels are the highest ever recorded. The rise in water-table has existed since the 1960 s, even during the severe droughts, and has increased during the past decade. The second part of the paper is the probable explanation of the significant long-term rise in the water-table: during the last few decades, environmen- tal changes due to a marked increase in cultivation had a larger impact than climatic fluctuations. In future decades hydrological evolution may differ from the present trend.

\section{Materials and methods}

\subsection{Regional features}

The study area is located at the S-W boundary of the large Iullemmeden basin (Fig. 1). Its upper surface is formed by a nearly horizontal laterite plateau cut by many sandy valleys of highly variable size. The differences in altitude never exceed $100 \mathrm{~m}$. Outcropping sediments, mainly silty sandstones, belong to the Continental Terminal, dated Eocene to Pliocene, and 
to the Quaternary. The present landscape is inherited from former wetter and drier conditions during the Quaternary (valley cutting, aeolian ergs, respectively). The Niger river, the only permanent surface water body, flows directly over the Pre-Cambrian basement.

The mean annual rainfall in Niamey (Fig. 1) was $565 \mathrm{~mm}$ for the 1905-1999 period. The rainy season begins in May and ends in October but $60 \%$ of the rainfall is concentrated in July and August (and 90\% between June and September). The mean annual temperature is $29^{\circ} \mathrm{C}$; the daily maximum can reach $45^{\circ} \mathrm{C}$ at the end of the dry season, in April. Potential evapotranspiration is about $2500 \mathrm{~mm} \mathrm{yr}^{-1}$ and may be lower than rainfall only in the middle of the rainy season in July and August. Vegetation is mainly tiger bush on the lateritic plateaux (shrub bush in banded pattern) and a patchwork of fallow savannah and millet fields on the sandy slopes and in the valleys (D'Herbès and Valentin, 1997).

Oustanding features of the hydrological working are now well established (Desconnets et al., 1997; Peugeot et al., 1997). Due to the degradation of the drainage network, the region is a juxtaposition of small endoreic catchments whose area is of the order of $1 \mathrm{~km}^{2}$. Depending on the characteristics of the soil and of each rain, a variable proportion of the rainwater concentrates into gullies and reaches the lowest part of the catchment, where a temporary pond generally exists. The small size of the elementary catchments and the high heterogeneity of rainfall distribution imply marked variation in time and space of surface runoff. Away from the ponds, water infiltration into the soil below 3-5 $\mathrm{m}$ does not occur or is very limited. It can be therefore considered that there is no significant diffuse deep percolation and that groundwater recharge is mainly, if not solely, due to seepage beneath the temporary ponds. Most of the water in the ponds rapidly infiltrates to the watertable through the unsaturated zone, the thickness of which varies between 0 and $75 \mathrm{~m}$. Annual percolation to the water-table, now often between 10 and $25 \mathrm{~mm}$, is also highly variable. But because of the extension and continuity of the phreatic aquifer over the whole area and because of limited groundwater recharge, the water-table is a very good integrator that allows to reconstruct hydrological evolution over several decades.
In the water-table, hydraulic gradients are low (less than $1 \%$ ) and there is no preferential direction of groundwater flow (Leduc et al., 1997). In concordance with the continental nature of the sedimentation, hydrogeologic parameters can vary sharply between 1 and $20 \%$ for porosity, and between $10^{-6}$ and $10^{-3} \mathrm{~m} \mathrm{~s}^{-1}$ for permeability. The median depth to the water-table is $35 \mathrm{~m}$ and the saturated thickness increases gently from 5 to $60 \mathrm{~m}$ towards the basin centre. Two deeper aquifers exist in the Continental Terminal but geological, hydrodynamic and isotopic data do not show any leakage to the water-table.

\subsection{Groundwater level data}

Most of the water-table level data used hereafter were collected during the past decade from a large number of wells with a measurement frequency ranging from one per 15 days to one per year. The second part of the data is made up of older, scarcer measurements, sometimes dating back to the beginning of the century; they give a much less continuous but long-term view of changes in the aquifer.

\subsubsection{Recent regular surveys}

The first survey, started in 1986, was made by the Niger Ministry of Hydraulics and concerned the region around Dantiandou (Fig. 1), inside our study area (Schroeter, 1993): about 80 measurements are available for each one of its 30 piezometers. The second survey began in 1991 as part of the HapexSahel international experiment and is still going on. More than 250 wells and boreholes are surveyed with a variable frequency: once or twice a month for about one hundred points, once to four times a year for the others, i.e. a total of over 15,000 measurements. Seven automatic level recorders complete the network. The second survey is now operated by IRD (Institut de Recherche pour le Développement, formerly ORSTOM) in Niger.

\subsubsection{Older, sparser measurements}

Many old measurements have been analysed. Their quality is extremely variable. Garde (1911) provided the first values from a few traditional wells near Niamey. Other measurements were made at the beginning of the 1950s. Later, Greigert (1957), Plote (1961), Tirat (1964) and Boeckh (1965) began 

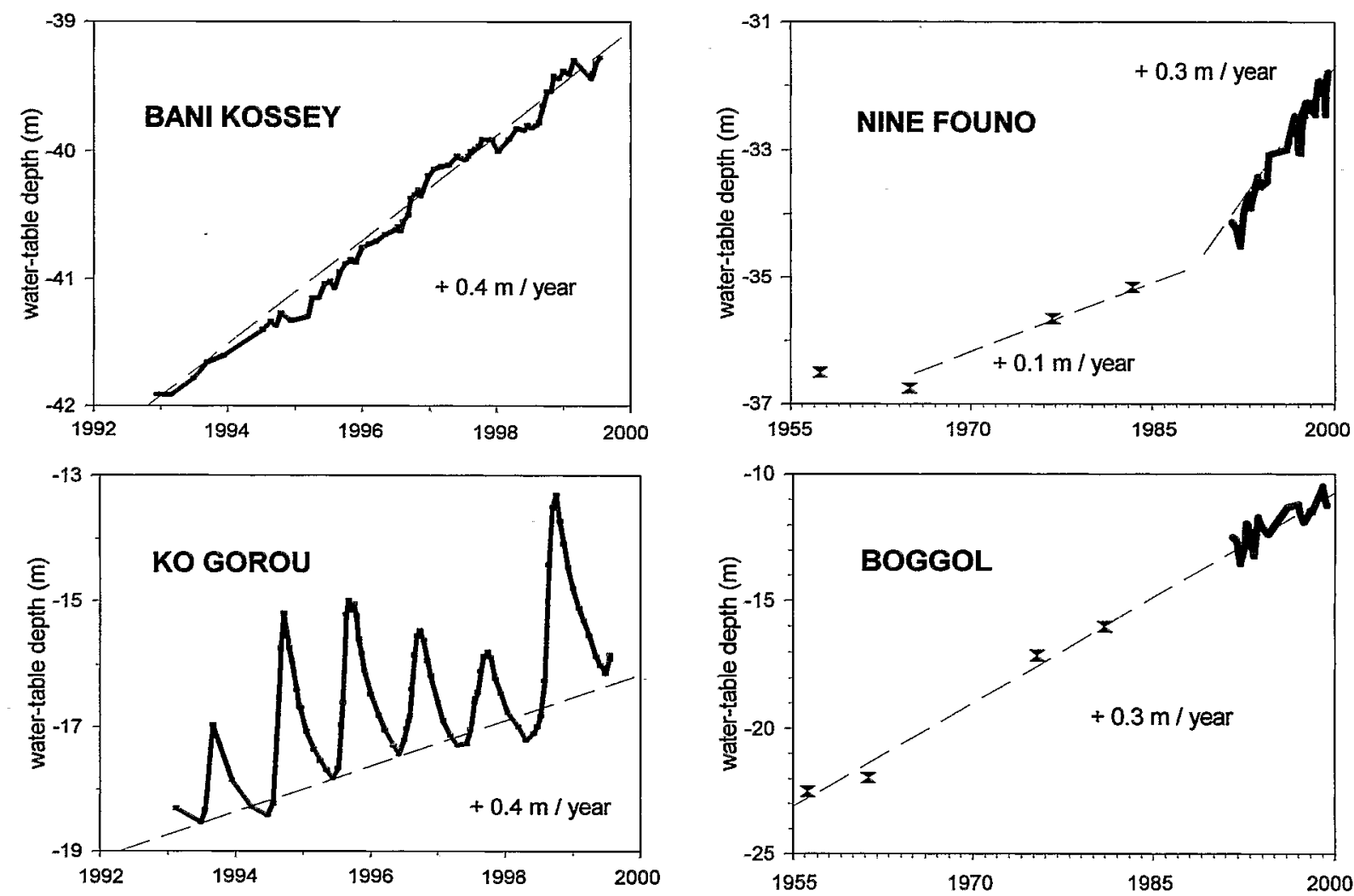

Fig. 2. Fluctuations in groundwater levels during the past decades: very regular rise in Bani Kossey; strong seasonal fluctuation and a more uneven rise in Kogorou; acceleration of the rise in Nine Founo; rather regular long-term rise in Boggol. These points are referred to as Ba, Ko, Ni and Bo in Fig. 1. 


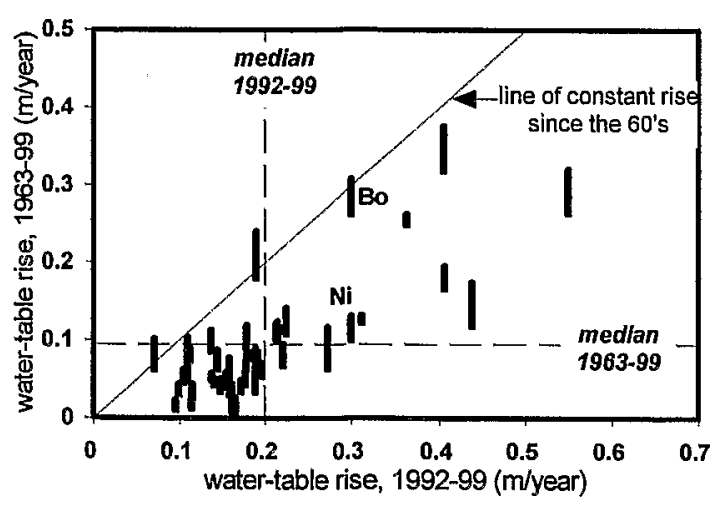

Fig. 3. Acceleration of the rise in groundwater level during the past decade: most points show a recent (1992-1999) rise that is more rapid than the long-term (1963-1999) rise. Error bars are very thin for 1992-1999 and greater for 1963-1999.

systematic water-table measurements, providing hundreds of data on both cemented and traditional wells. We searched in the original ground sheets for exact dates and locations of the wells or boreholes visited, which were rarely specified in the reports. Further studies are more rare and, with the exception of the CONSIND (1973) technical report, water-table measurements are exclusively related to drilling or to rehabilitation of cemented wells by OFEDES (National Niger Groundwater Office). At the beginning of the 1980s, a few water-table measurements in the south of the study area completed the available data set (Brodbeck, 1986). The major difficulty when dealing with old, isolated data is to connect them with the recent measurements.

\subsubsection{Representativeness of measurements}

Different types of errors can upset the comparison of measurements. The first is wrong identification of the well. Many wells in the 1950s and 1960s were traditional wood-lined wells, which slump easily with age and which may collapse and disappear. A potential source of error is also confusion between different wells in the same village. The second type of error is a change in the reference level for measurement. The rims of the wells can be heightened as a result of repairs or sanding up. The third type of error is the water level drawdown due to pumping: it is often small but can reach $2.5 \mathrm{~m}$ in the most unfavourable cases. It depends on the daily pumping, which is related to the size of the population and the number of cattle. At a larger time scale, pumping is maximum at the end of the dry season and minimum in July and August. Another type of error is due to seasonal changes in the water-table: during the rainy season, some wells have water levels that rise by up to $6 \mathrm{~m}$. Marked differences can therefore be found when comparing measurements made in the same well at different times of the day or of the year. These difficulties, detailed in Favreau et al. (2000), have been overcome by field inquiries about the characteristics and history of the wells and with a fine analysis of the local fluctuations using numerous observations.

\subsection{Radio-isotopes}

In the study area, 45 groundwater samples were collected for isotopic analysis of ${ }^{3} \mathrm{H}$ and 64 of ${ }^{14} \mathrm{C}$ (Leduc et al., 2000). The ${ }^{3} \mathrm{H}$ content varied between $20 \mathrm{TU}$ and the detection threshold (i.e. often 1 or $2 \mathrm{TU}$ ), with a median lower than $2 \mathrm{TU}$. The ${ }^{14} \mathrm{C}$ activities varied between 53 and $126 \mathrm{pmC}$ with only six samples lower than $70 \mathrm{pmC}$. Groundwater ages inferred from radioactive decay did not require any correction because dissolved inorganic carbon comes only from atmosphere through soil respiration.

These data were used in a simple model of perfect mixing in the saturated zone that fitted well with the hydrologic functioning of this semi-arid area (Leduc et al., 1996). We calculated the renewal rate, i.e. the ratio of annual percolation to the water-table and of total amount of water in the aquifer. The ${ }^{3} \mathrm{H}$ interpretation gave a renewal rate varying between $4.8 \%$ and less than $0.1 \%$ per year, with a median of about $0.2 \%$. The ${ }^{14} \mathrm{C}$ interpretation gave a renewal rate between 0.01 and $6 \%$ per year with a median value of $0.1 \%$.

\section{Results}

\subsection{Analysis of hydrodynamic data}

The very first measurements made at the beginning of the century (Garde, 1911), though few and rather imprecise (uncertainty of about $2 \mathrm{~m}$ ), converge to show levels close to levels in the 1960s and much lower than today by up to $12 \mathrm{~m}$. Though much precaution must be taken in the interpretation of such results, these rises did not occur by chance and reveal a 


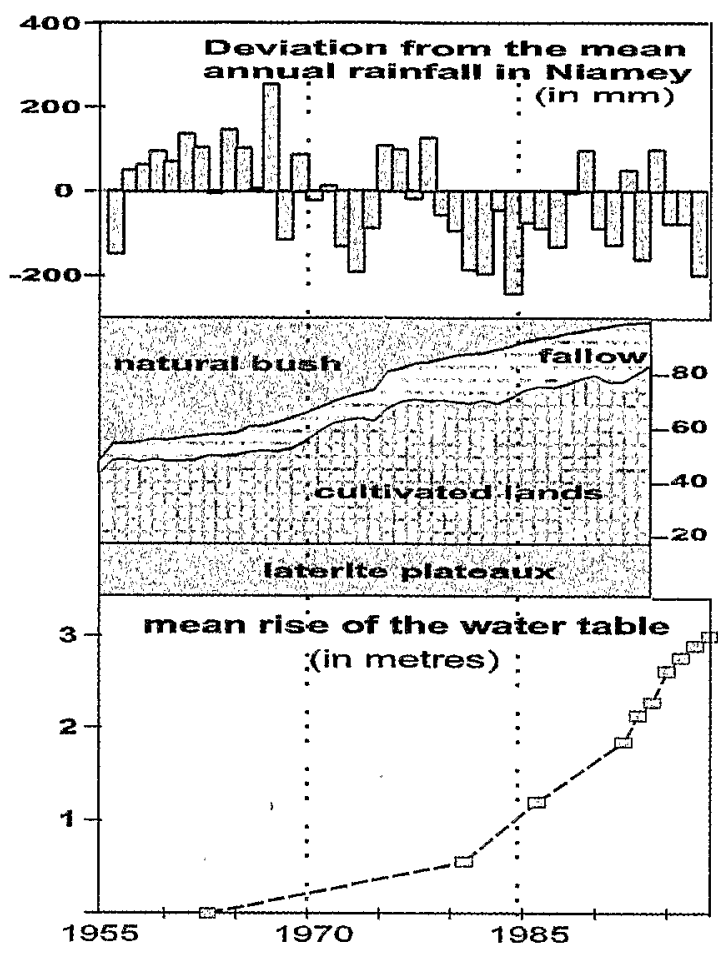

Fig. 4. Comparative changes in rainfall (upper diagram), in land-use (central diagram) and in water-table level (lower diagram) from 1955 to 1997. The deviation from the mean annual rainfall in Niamey $(565 \mathrm{~mm})$, expressed in $\mathrm{mm}$, shows a wet period before 1970 and a long drought afterwards. Land-use is expressed as a percentage of the total surface area of the study zone. The mean rise in the water-table, calculated from over 50 points, is expressed in $\mathrm{m}$ above levels in the early $1960 \mathrm{~s}$.

general increase in groundwater resources. Measurements taken from the end of the 1950s and the beginning of the 1960 s are more precise, more numerous and therefore more convincing. All indicate levels lower than today, from less than $1 \mathrm{~m}$ to more than $10 \mathrm{~m}$ lower, often 2-4 m lower (Figs. 2-4). The increase in groundwater resource ranges between $0 \%$ and more than $150 \%$ of the water available at the beginning of the 1960s, about $15 \%$ in median. Absolute increases are higher near the Niger River than in the east, probably because of the lower hydrodynamic properties of the aquifer to the west. Between the end of the 1960s and the middle of the 1980 s, water-table fluctuations are poorly documented. Some points show a continuous rise when others may have undergone an initial increase, followed by a drop, probably due to the severe droughts of 1973 and 1981-1984. In the middle of the 1980s, about one hundred levels were measured; they are lower than those that date from the 1990s and are in good agreement with changes observed during the past decade.

Since 1991, we have noticed a rise in the watertable year after year (Leduc et al., 1997). The rise ranges from 0.01 to more than $0.45 \mathrm{~m} \mathrm{yr}^{-1}$ (Fig. 1), with a median value of $0.20 \mathrm{~m} \mathrm{yr}^{-1}$. A detailed analysis of some 175 significant records showed that there is no systematic relationship between the local values of the long-term rise intensity and those of the seasonal water-table fluctuation (Fig. 2): places with marked seasonal fluctuations can rise extremely fast (e.g. $0.40 \mathrm{~m} \mathrm{yr}^{-1}$ in Kogorou) or rather slowly, and points without any seasonal fluctuation present the same extremes (e.g. $0.40 \mathrm{~m} \mathrm{yr}^{-1}$ in Bani Kossey). The relationship between intensity of the rise and hydrogeologic characteristics is suggested by the spatial distribution of the rise (Fig. 1): many big increases are located in the west, where the aquifer is thinner and poorly transmissive and low rises are mostly located in the east, in the coarser alluvial deposits of the dallol Bosso (Fig. 1).

Fig. 3 compares the mean rise calculated for the last decade (1992-1999) to the long-term rise (19631999). First, the recent rise is generally higher than the long-term rise. Second, points with a marked recent rise (about $0.30 / 0.40 \mathrm{~m} \mathrm{yr}^{-1}$ ) have also a significant long-term rise and points with a low recent rise $\left(\sim 0.10 \mathrm{~m} \mathrm{yr}^{-1}\right)$ also have a low long-term rise. The recent rise appears as an enhancement of a process that has been at work for several decades.

Roughly beneath the Dantiandou fossil valley, a large, closed potentiometric depression exists (Leduc et al., 1997; Favreau, 2000). As elsewhere in the Sahel, it can only be explained by a weak horizontal flux and a local evaporation outflow that is higher than deep percolation. Its very slow water motion is confirmed by groundwater 'ages' estimated from isotopes, older here than in the rest of the aquifer. During the recent decades, the water-table has risen in this area in the same way as in most of the aquifer and the shape of the depression remains. The end of this transient state could be the disappearance of the closed depression.

In the east, the very few measurements made in the dallol Bosso represent the only exception, with past 
levels similar or even higher than present ones. In this large, flat, sandy valley, the hydrologic regime is completely different from the rest of the aquifer for several reasons: the water-table is always close to the ground surface; recharge is probably a direct process; there are many large trees that take a large proportion of their water requirements from the water-table; land clearing is probably much older.

\subsection{Estimate of recharge from hydrodynamic data}

At the local scale, the water-table rise can vary greatly from one year to the next, depending on rainfall variability, hydrogeologic characteristics and infiltration discontinuity. Some places have a very smooth and regular rise while others change abruptly: during a very rainy year, the annual rise may be up to 10 times higher than the long-term rise. For many points, half the rise during the 1990s was due to groundwater recharge that occured in two years: 1994 and 1998. An estimate of aquifer recharge based on too few points or too few years would therefore be very risky.

At the scale of the whole study area, the mean rise in the water-table was 0.10 and $0.47 \mathrm{~m} \mathrm{yr}^{-1}$ for the years 1997 and 1998, respectively. The mean interannual rise during the last decade is $0.20 \mathrm{~m} \mathrm{yr}^{-1}$. Assuming a porosity of $10 \%$, this represents an increase in the groundwater reserve of $20 \mathrm{~mm} \mathrm{yr}^{-1}$. The total recharge must be higher than this reserve increase because the study area is not entirely endoreic (springs in the Niger valley, outflow to the south) and also because of pumpings but the difference is probably small.

\subsection{Estimate of recharge from radio-isotopes}

Assuming a porosity of $10 \%$ and a mean saturated thickness of $30 \mathrm{~m}$, half of the samples should imply an annual groundwater recharge between 1.5 and $15 \mathrm{~mm}$. Median values for recharge should be 6 and $3 \mathrm{~mm} \mathrm{yr}^{-1}$ according to ${ }^{3} \mathrm{H}$ and ${ }^{14} \mathrm{C}$, respectively. Because of the apparent old age of the water, isotopic values may be considered as integrated in time. This should result in a significant smoothing of the annual heterogeneous recharge. The persistence of heterogeneity over the long-term shows a highly heterogeneous pattern of recharge over the Niamey degree square.
The amount of recent groundwater recharge calculated from hydrogeologic data exceeds $20 \mathrm{~mm} \mathrm{yr}^{-1}$ during the past decade. This is higher than the isotopic value (around $5 \mathrm{~mm} \mathrm{yr}^{-1}$ ), representative of a much longer period. This is a remarkable confirmation of the marked increase in the rise since the $1980 \mathrm{~s}$, already noted in water-table records.

\section{Discussion}

Some theoretical explanations for this rise are not valid. Artificial recharge by irrigation can be eliminated because, apart from the Niger valley, which is a natural outlet for the water-table, there is no irrigation. Overflow from artesian boreholes could be important only on a very local scale but boreholes are too few to have an overall impact on the aquifer, and the rise is obvious even in places that are very far away from a borehole. Moreover in many places, the rise began before the drilling of boreholes. We must also eliminate a reduction in pumping because of population growth ( $4 \%$ per year) and an increase in the total number of wells which have increased groundwater extraction, which, in turn, should have led to a drop rather than a rise in the water-table. Leakage from deeper aquifers is not a viable explanation either because, among other arguments, the chemical content of their fossil waters would be easily identifiable in the poorly mineralized water-table. Other explanations for the water-table rise must be sought.

\subsection{First possible explanation: the impact of variations in rainfall}

As everywhere in the Sahel, rainfall in S-W Niger is highly variable in time and space. A very dense raingauge network in the Niamey degree square shows that every year the ratio between the maximum and the minimum recorded annual rainfall is at least two, with a distance between the two extremes of less than $80 \mathrm{~km}$ (D'Amato and Lebel, 1998). Extreme values for annual rainfall in Niamey are $281 \mathrm{~mm}$ in 1915 and $1161 \mathrm{~mm}$ in 1998 . The average for the period 19501970 is $619 \mathrm{~mm}$, i.e. $10 \%$ above the long-term average, and $503 \mathrm{~mm}$ for the period 1970-1990, i.e. about 10\% below. According to Le Barbé and Lebel (1997), the decrease in rainfall between 1950-1970 and 1970-1990 was due to a decrease in the number of 
rainy events ( $-30 \%$ in August) rather than to a decrease in the mean event rainfall.

Groundwater recharge can occur even in drought years because it is essentially induced by rainy events of over $20 \mathrm{~mm}$. Annual rainfall, highly correlated with the sum of the heaviest rainfalls, gives a rough idea of the recharge ability of any given year.

The first possible explanation for the recent rise in water-table could be a link with variations in rainfall: the 1990 s, which were much wetter than the 1980 s, could have resulted in greater recharge. However, previous variations in rainfall and groundwater levels refute such a simple correlation. The relative drop in rainfall of 20\% between 1950-1970 and 1970-1990 should have had a significant impact on water resources but, in fact, the water-table level in recent years is higher for lower rainfall than it was during the 1960s. The hydrological functioning therefore appears to be more complex than a linear rainfallrecharge correlation.

The lack of one simple relationship shows that the main process at work is long-term hydrological change that is little influenced by rainfall. Of course, this does not mean that rainfall has no influence on fluctuations in the groundwater. For instance, the relative drop of some points between the beginning of the 1960 s and the end of the 1980s could be an indication of the influence of the severe droughts. Moreover, the enhancement of the rise during the past decade could also be interpreted as a positive combination of a long-term process and greater recharge due to a return to wetter years.

\subsection{Second possible explanation: changes in land-use}

Land clearing was limited during the first decades of the XXth century, but since the 1950s it has been increasing due to rapid population growth. Aerial photographs and satellite images quantify this development. Using Loireau's (1998) ground survey, Fig. 4 shows changes in the landscape in a representative area of about $600 \mathrm{~km}^{2}$ east of Niamey for the period 1955-1995. Cultivated area increased from about $27 \%$ of the total cultivable area to nearly $100 \%$. Loireau (1998) points out that the natural wooded savannah has almost disappeared, millet fields and associated fallows have invaded the landscape and the fallow period has been shortened. Deforestation has also affected the non-cultivable laterite plateaux, especially close to Niamey, for the production of wood as a primary source of energy.

\subsubsection{Reduced transpiration loss}

Most evapotranspiration occurs in the first $3 \mathrm{~m}$ of the soil, which contain nearly all the root biomass in the Sahel (e.g. Nizinski et al., 1994). The clearing of natural vegetation could have resulted in reduced evapotranspiration and subsequently in increased drainage. In fact, recent works in our study area (e.g. Peugeot et al., 1997) have shown that in almost all cases, except in temporary ponds, the rainfall does not infiltrate into the soil deeper than $3.5 \mathrm{~m}$. Changes in vegetation during recent decades have modified water distribution but the lack of diffuse groundwater recharge remains a fundamental feature.

A change in direct uptake from the water-table could be considered a possible cause, since a small proportion of the water used by vegetation may come from deep underground: Canadell et al. (1996) cite roots of semi-arid Boscia, Acacia and arid Prosopis at a depth of more than $50 \mathrm{~m}$. In our region, welldiggers report roots of Acacia albida at great depth, even below $40 \mathrm{~m}$. This root uptake is probably negligible under the lateritic plateaux where the watertable is $60-75 \mathrm{~m}$ below and where transpiration requirements of the main shrubs, Combretum micranthum and Guiera senegalensis, come from the top $4 \mathrm{~m}$ of the soil (Gaze et al., 1998). It could be more important in the valley bottoms where the depth to the saturated zone is often between 15 and $25 \mathrm{~m}$ and where trees are often taller and more numerous. Land clearing has affected large trees much less than small bushes but quantification of a smaller root uptake is very difficult. It seems tenuous in comparison with changes in hydrological functioning.

\subsubsection{Changes in hydrological functioning}

Runoff increase due to a change in land-use is in fact the most reliable hypothesis for the long-term rise in the water-table. The surface characteristics, including faunal activity, vegetation cover and surface roughness, are very sensitive to environmental modifications such as land clearing or recurrent droughts, which tend to enhance the runoff/infiltration ratio (Casenave and Valentin, 1992). Land clearing during the past decades has resulted in a decrease in the 
content of organic matter in the top soil which, combined with its large proportion of silt and clay, has induced the development of surface crusting, where runoff is higher than over vegetated areas. With reference to the classification system of Sahelian unit surfaces (Casenave and Valentin, 1992), a mean runoff ratio (i.e. ratio between runoff and rainfall) was calculated for small areas up to $5000 \mathrm{~m}^{2}$. D'Herbès and Valentin (1997) divided the Niamey degree square into different classes, based on surface conditions interpreted from SPOT images: plateaux represented $28 \%$, hillslopes $11 \%$, old shrub fallows $20 \%$, mid-old and recent fallows $19 \%$ and millet fields on hillslopes and valley bottoms $22 \%$. Their mean runoff ratio was $26 \%$ for old fallow and $32 \%$ for mid-old or recent fallow and millet field: the reduction in natural vegetation and old fallow should lead to an increase in surface runoff. In practice, the increase in the runoff ratio cannot be transposed unchanged to the larger scale of a whole endoreic catchment (a few $\mathrm{km}^{2}$ ) because of the mosaic of fields and fallows. The overall runoff of a catchment is not the sum of elementary runoff over each parcel, but a much more complicated combination (Peugeot et al., 1997).

In our study area, we have no old measurement of surface runoff that could be directly compared with our recent observations. Nevertheless, indirect evidence is available. Old villagers assert that present ponds are more numerous and contain more water than during the 1960s. Analysing aerial photographs between 1962 and 1994, Mougenot and Timouk (personal communication) noted considerable widening of gullies, by up to four times. This increase in erosion is due to an increase in surface runoff, which leads to an increase in the amount of water in the ponds and consequently to a greater groundwater recharge. Unfortunately, our approach to hydrological developments in the Niamey area remains qualitative: we cannot directly correlate the amounts of erosion, runoff and recharge.

In other parts of the Sahel, surface runoff has also increased considerably between the 1960s and the 1980s. For example, Albergel et al. (1992) cited the Gagara catchment, in the north of Burkina Faso, which at least doubled its runoff ratio between 1956-1963 and 1980-1985. Pouyaud (1987) also distinguished large basins, where the total runoff and the runoff ratio decreased during the drought decades, from small or medium catchments (less than $10,000 \mathrm{~km}^{2}$ ), where the runoff ratio has increased.

\subsection{Comparison with other semi-arid regions}

We do not believe in the uniqueness of the phenomenon that has been observed in the Niamey region. It is consequently necessary to search for modifications in the water-table in other semi-arid areas. Other data are available in the rest of the Iullemmeden basin in Niger. They are often less numerous and their interpretation is more difficult. Different regions of the Continental Terminal outcrops (i.e. the south-western half of the Iullemmeden basin) have also been surveyed since the end of the 1980s. All show an interannual rise (Schroeter, 1993). Elsewhere in the basin, near Tessaoua (i.e. on its south-eastern fringe, cf. Fig. 1), the water-table rose by up to $3 \mathrm{~m}$ between 1964 and 1992; this development was also linked by Boeckh (1992) to land clearing. The development described near Niamey therefore appears to be representative of a phenomenon that is active throughout the Iullemmeden basin.

The other large sedimentary basin in Niger, the lake Chad basin, shows a different and more complex evolution, in particular because of interactions between the drainage network and the water-table. Close to lake Chad, whose northern pond has often completely dried up in recent decades, the water-table has fallen by up to $8 \mathrm{~m}$ (Leduc et al., 1998). In the deep Kadzell depression, the water-table has been falling at a rate of about $0.01-0.04 \mathrm{~m} \mathrm{yr}^{-1}$ since 1990. Both are probably linked and are not representative of the whole water-table. Elsewhere, no clear trend can be seen for the long-term change. This could be explained by a lower annual groundwater recharge rate, and consequently lower sensitivity to recent changes in rainfall and in the environment, and also by a much lower anthropogenic impact, due to a very low population density (Leduc et al., 2000).

On the south-western fringe of the lake Chad basin, in the Bornu province of Nigeria, Barber and Dousse (1965) cited a very high rise, of up to $20 \mathrm{~m}$, in the water-table between 1930 and 1950 . The rise has also been explained by intense land clearing that increased surface runoff and resulted in increàsed river flow that, in turn, induced an increased recharge through 
the river banks as evidenced by the localized groundwater rise, which was confined to the neighbourhood of the rivers.

Elsewhere in the Sahel, the most common trend is a decrease in level. In Chad, Bichara et al. (1989) reported a constant drop in the water-table since the beginning of the 1960s. In fractured aquifers of Burkina-Faso (Martin and Thiery, 1986) and of Mali (DNHE/PNUD, 1989), slightly more humid than our study area, a decrease of 0.45 and $0.60 \mathrm{~m} \mathrm{yr}^{-1}$, respectively, was measured during the 1980 s caused by the severe droughts. Fractured aquifers of the Sahel are generally much smaller than our study area and their limited resources make them bad time integrators, as they are too sensitive to very recent fluctuations in climate.

In the well studied Kalahari (e.g. Selaolo, 1998), groundwater recharge is often estimated between 1 and $10 \mathrm{~mm} \mathrm{yr}^{-1}$ depending on methods and places but no changes in water-table have been noted at the human scale.

In other semi-arid regions of the world, the same process may be present but the natural change is often hidden by over-exploitation of groundwater resources, as is the case in the Southern High Plains aquifer, USA (Wood and Sanford, 1995). In southeast Australia, many studies of chloride profiles in the unsaturated zone have shown that clearing of native vegetation leads to a marked increase in direct recharge: averages are $7 \mathrm{~mm} \mathrm{yr}^{-1}$ in natural conditions and $29-70 \mathrm{~mm} \mathrm{yr}^{-1}$ in deforested areas (e.g. Thorburn et al., 1991). This last case shows a relative recharge increase close to ours (about one order of magnitude) but the process is fundamentally different: recharge is diffuse and direct in Australia whereas it is localized and indirect in Niger.

\section{Conclusions}

Our estimates of groundwater recharge before and after land clearing are consistent with estimates from other semi-arid areas in equivalent settings. In such regions, local methods (e.g. isotope or chloride profiles) are fragile because their results are significant only at the sampling points; they require a precise input signal, largely unknown in semi-arid areas; they can be disturbed by macroporosity. We have also used these methods but the obvious rise in the water-table throughout the study area is a much better demonstration of the significant modification in the waterbudget since 1950 .

Future evolution is largely unknown. During recent decades, water distribution has been much more influenced by land clearing than by climatic variations: in many cases, the droughts of the 1970s and 1980s are not even detectable in the long-term rise in the watertable. We are unable to estimate the influence of global warming on rainfall. Increase in surface runoff should soon come to an end because most of the cultivable land is now cultivated. However, the watertable could continue to rise for a much longer time because of the steep increase in deep percolation to an aquifer with poor hydrogeologic characteristics. More subtle phenomena could also operate. A marked increase in evaporation in the few places where the water-table is close to the ground surface could locally compensate for greater recharge. But the more important change should be modification in crusted areas. The finest particles are removed by wind and water erosion, which partly depends on cultivation practices (Ambouta et al., 1996). De Rouw and Rajot (submitted for publication) show that during the first $40 \mathrm{yr}$ of cultivation, organic matter has decreased much more quickly than fine particles; after about $40 \mathrm{yr}$, so much clay and silt has been removed by erosion that crust could not exist any longer and ground surface has turned more sandy. Surface runoff should consequently decrease in the oldest fields. A new equilibrium in the water-table is therefore unlikely to be achieved during the next decade. The study of this transient evolution will require a new longterm survey.

\section{Acknowledgements}

We sincerely thank the previous hydrogeologists in Niger who gave us information about old water-table levels data, namely Francis Balmer, Guy Bernert, Eduard Boeckh, Jacques Greigert, Walter Neumann, Hartmut Paschen and Michel Tirat. Particular thanks are expressed to Abdou Guéro (Ministry of Hydraulics) and Maoudé Koroney (OFEDES) who helped us in consulting their archives. The ground survey has been mainly financed by the Swiss and French 
Cooperations and IRD, and also partly supported by the PNRH (French programme of hydrological research). We also thank C. Valentin, M. Sophocleous and an anonymous reviewer for their comments.

\section{References}

Albergel, J., Casenave, A., Ribstein, P., Valentin, C., 1992. Aridité climatique, aridité édaphique: étude des conditions de l'infiltrabilité en Afrique tropicale sèche. L'aridité: une contrainte au développement: caractérisation, réponses biologiques, stratégies des sociétés, ORSTOM, Didactiques, pp. 123-130.

Ambouta, J.M.K., Valentin, C., Laverdière, M.R., 1996. Jachères et croûtes d'érosion au Sahel. Sécheresse 7, 269-275.

Barber, W., Dousse, B., 1965. Rise in the water-table in parts of Potiskum area. Bornu state. Further observations. Geol. Surv. Niger. 9, 1-21.

Bichara, D., Safi, A., Schneider, J.L., 1989. La précarité ou même 1'absence d'alimentation de la nappe phréatique en zone nordsahélienne du Tchad. Résultats d'un quart de siècle de surveillance piézométrique. C. R. Acad. Sci. Paris 309 (II), 493-496.

Boeckh, E., 1965. Contribution à l'étude hydrogéologique de la zone sédentaire de la république du Niger. Technical report, BRGM/BFBH, DAK65-A20, Dakar, Sénégal.

Boeckh, E., 1992. Mise à disposition d'un expert hydrogéologue auprès du projet hydraulique rurale dans l'arrondissement de Tessaoua (PHRT). Partie II: rapport technique. Technical report, GTZ, Tessaoua/Hanovre, Germany.

Brodbeck, J.F., 1986. Valeur de l'inventaire (IRH/DRE) des points d'eau, base d'un futur guide hydrogéologique. Technical report, IUED-DRE, Niamey, Niger.

Canadell, J., Jackson, R.B., Ehleringer, J.R., Mooney, H.A., Sala, O.E., Schulze, E.D., 1996. Maximum rooting depth of vegetation types at the global scale. Oecologia 108, 583-595.

Casenave, A., Valentin, C., 1992. A runoff capability classification system based on surface features criteria in semi-arid areas of West Africa. J. Hydrol. 130, 231-249.

CONSIND, 1973. Construction de 259 puits au Niger. Rapport confidentiel final. Technical report, Niamey, Niger.

D'Amato, N., Lebel, T., 1998. On the characteristics of the rainfall events in the Sahel with a view to the analysis of climatic variability. Int. J. Climatol. 18, 955-974.

De Rouw, A., Rajot, J.L. Soil organic matter, nutrients and erosion in Sahelian farming systems based on manuring or fallowing. Agriculture, Ecosystems and Environment. Submitted for publication.

Desconnets, J.C., Taupin, J.D., Lebel, T., Leduc, C., 1997. Hydrology of the HAPEX-Sahel Central Super-Site: surface water drainage and aquifer recharge through the pool systems. J. Hydrol. 188-189, 155-178.

D'Herbès, J.M., Valentin, C., 1997. Land surface conditions of the Niamey region: ecological and hydrological implications. J. Hydrol. 188-189, 18-42.

DNHE/PNUD, 1989. Schéma directeur de mise en valeur des ressources en eau du Mali. Technical report, MLJ/84/005, Bamako, Mali.
Favreau, G., 2000. Caractérisation et modélisation d'une nappe phréatique en hausse au Sahel: dynamique et géochimie de la dépression piézométrique naturelle du kori de Dantiandou (sudouest du Niger). PhD thesis, Paris XI University.

Favreau, G., Leduc, C., Marlin, C., 2001. Représentativité de l'échantillonnage géochimique et hydrodynamique en nappe libre de milieu semi-aride. J. Afr. Earth Sci. (in press).

Garde, G., 1911. Description géologique des régions situées entre le Niger et le Tchad et à l'Est et au Nord-Est du Tchad. PhD thesis, Paris University, France.

Gaze, S.R., Brouwer, J., Simmonds, L.P., Bromley, J., 1998. Dry season water use patterns under Guiera senegalensis L. shrubs in a tropical savanna. J. Arid Environ. 40, 53-67.

Greigert, J., 1957. Introduction à la connaissance hydrogéologique du bassin occidental du Niger (rapport fin de campagne 19551956). Troisième partie. Les principales nappes du bassin occidental du Niger. Technical report, Direction Fédérale des Mines et de la Géologie, Dakar, Sénégal.

Le Barbé, L., Lebel, T., 1997. Rainfall climatology of the HapexSahel region during the yr 1950-1990. J. Hydrol. 188-189, 4373.

Leduc, C., Taupin, J.D., Le Gal La Salle, C., 1996. Estimation de la recharge de la nappe phréatique du Continental Terminal (Niamey, Niger) à partir des teneurs en tritium. C. R. Acad. Sci. Paris 323, 599-605.

Leduc, C., Bromley, J., Schroeter, P., 1997. Water-table fiuctuation and recharge in semi-arid climate: some results of the HAPEXSahel hydrodynamic survey (Niger). J. Hydrol. 188-189, 123138.

Leduc, C., Salifou, O., Leblanc, M., 1998. Evolution des ressources en eau dans le département de Diffa (bassin du lac Tchad, sudest nigérien). Water resources variability in Africa during the XXth century. Proceedings of the Abidjan 98 Conference, November, IAHS publ. 252, pp. 281-288.

Leduc, C., Favreau, G., Marlin, C., Dray, M., 2000. Comparison of recharge estimates in the two largest aquifers of Niger based on hydrodynamical and isotopic data. Tracers and modelling in hydrogeology. Proceedings of the TraM'2000 Conference, May, IAHS publ. no. 262, pp. 391-399.

Loireau, M., 1998. Espaces, ressources, usages: spatialisation des interactions dynamiques entre les systèmes sociaux et les systèmes écologiques au Sahel nigérien. $\mathrm{PhD}$ thesis, Montpellier III University, France.

Martin, J., Thiery, D., 1986. Analyse d'une longue série piézométrique au Burkina-Faso. Extension de données et première estimation de la recharge par les pluies. Technical report, no. 86/14, BRGM, Orléans, France.

Nizinski, J., Morand, D., Fournier, C., 1994. Actual evapotranspiration of a thorn scrub with Acacia tortilis and Balanites aegyptiaca (North Senegal). Agric. For. Meteorol. 72, 93-111.

Peugeot, C., Esteves, M., Galle, S., Rajot, J.L., Vandervaere, J.P., 1997. Runoff generation processes: results and analysis of field data collected at the East Central Supersite of the HAPEX-Sahel experiment. J. Hydrol. 188-189, 179-202.

Plote, H., 1961. Reconnaissance hydrogéologique du Liptako et des régions adjacentes. Technical report, BRGM, Paris, France.

Pouyaud, B., 1987. Variabilité spatiale et temporelle des bilans 
hydriques de quelques bassins versants d'Afrique de l'ouest en liaison avec les changements climatiques. The influence of climate change and climatic variability on the hydrologic regime and water resources. Proceedings of the Vancouver Symposium, August, IAHS publ., 168, pp. 447-461.

Schroeter, P., 1993. Les fluctuations des niveaux d'eau dans les nappes du Continental Terminal et de la formation du Tchad. Premières interprétations, période, 1987-1993. 'Technical report, DRE Ministère de 1'Hydraulique et de l'Environnement, Niamey, Niger.

Selaolo, E.T., 1998. Tracer studies and groundwater recharge assessment in the eastern fringe of the Botswana Kalahari. $\mathrm{PhD}$ thesis, Free University, Amsterdam, The Netherlands.

Thorburn, P.J., Cowie, B.A., Lawrence, P.A., 1991. Effect of land development on groundwater recharge determined from nonsteady chloride profiles. J. Hydrol. 124, 43-58.

Tirat, M., 1964. Contribution à l'étude hydrogéologique du Continental Terminal. Technical report, BRGM, NIA.64.A1, Niamey, Niger.

Wood, W.W., Sanford, W.E., 1995. Chemical and isotopic methods for quantifying ground-water recharge in a regional semi-arid environment. Ground Water 33 (3), 458-468. 